\title{
Social Space for Self-Organising: An Exploratory Study of Timebanks in Finland and in the UK
}

\author{
Teppo Eskelinen \\ Department for Social Sciences and Philosophy \\ University of Jyväskylä \\ Email: teppo.h.i.eskelinen@jyu.fi
}

\begin{abstract}
The article examines the challenges to self-organisation and upscaling of alternative economies from the viewpoint of defending and negotiating social space. Timebanks in Finland and the UK are presented as examples, analysing the difference of defending such social space in the contexts of a traditional welfare state (in the case of Finland) and an austerity-driven government with a "Big Society" ideology (in the case of UK). Both systems of government present different kinds of pressures on timebanks, pushing them to a given ontological categories and to action in accordance with pre-defined political goals. This difference, along with timebank reactions and the question of prospects of opening ontological space, is analysed through material from observation, interviews with timebanks activists and brokers, and survey data from timebank users.
\end{abstract}

Keywords: Timebanks, community building, alternative economies, social ontology, governance, volunteerism

\section{Introduction}

Self-organised small-scale economic systems have recently received considerable attention (Gibson-Graham, 2008; Healy, 2009; North, 2007). Alternative exchange systems called timebanks are often seen as representative examples of these "community economies" (Cahn, 2000; Joutsenvirta, 2016). They combine social activism and alternative economic exchange with an egalitarian system of rewarding input, which recognises all 
skills within the community as valuable. Indeed, timebanks are seen by their activists and supporters as creating new, more locally controlled and more humane economic practices.

Timebanks see themselves as operating in the social space of "the commons", transcending dichotomies such as government/market and voluntary/commercial (Benkler, 2006; Ostrom, 1990). Indeed their system of organisation deviates from the organisational logic of governments, markets and NGOs. Further, their approach deviates from the commercial "sharing economy" (Botsman \& Rogers, 2011), as timebanks insist on an alternative conception of value, whereas in fashionable "sharing economy" initiatives, value often turns out to hardly deviate from the capitalist conception. While some timebanks see themselves as complementary to the capitalist economy, others see themselves as articulating a set of values, which could eventually inform a comprehensive alternative to capitalism.

While earlier scholarship on timebanks has focused mostly on their organisation (Laamanen \& den Hond, 2015) and social impact (Ozanne, 2010; Seyfang, 2003), in this article I will analyse timebanks from the viewpoint of the possibility of operating within a distinct social domain. This social domain refers to a category of organisation, valuation and discourse, which cannot be reduced to existing categories (such as government/market or voluntary/commercial). Crucially, even though timebanks see themselves as operating within the "commons" (Bollier \& Helfrich, 2012; Ostrom, 2010), they are unavoidably embedded in a wider societal context governed through other categories. This creates a constant need to negotiate their position. The question posed in this article then is, what kinds of external pressures timebanks face as they try to maintain, defend and negotiate this social space. This question will be explored by analysing data comprising of interviews, observation and documents.

The analysis is based on an exploratory study on timebanks in two countries, Finland and the United Kingdom. This setting enables a discussion on the role of political systems in the formation of the social space available to timebanks, as any political system will need to decide how it perceives timebanks in terms of categorisation. The political systems discussed in relation to timebanks are the welfare state and "Big Society". The former refers to the Nordic tradition, combining high taxation and universal service provision, while the latter is a more recent political concept coined in the UK, referring to a combination of austerity and privatisation of public services with the promotion of community development and decentralised governance (Coote, 2011; Smith, 2010). 
The article proceeds as follows: first, I will briefly introduce the practice and ideology of timebanking and its brief history in Finland and in the UK. Second, the issue of social space for self-organisation will be presented theoretically. Section three consists of presentation of the data and the methodology of the study. In the following three sections, I will present the analysis: government responses to timebanks, along with notions on negotiating with commercial insurance companies. The penultimate section proceeds with an analysis of the reactions from the point of view of the timebanks to these external pressures. The article finishes with a conclusion.

\section{Timebanking: Ideology and Background}

Timebanking is based on a specific method of accounting in which time is used as "currency". The currency is institutionalised through an accounting system, in which the provider of the service is credited and the recipient of the service is debited the duration of the provided service. Members announce skills and needs, after which these skills and needs are "matched" by a "broker", or by the members themselves (Simon, 2010). Practically, services range from everyday assistance around the house, such as minding pets, to professional services, such as language translation. The practice emerged as a method of communitybuilding (Lasker \& Collom, 2011; Seyfang, 2004), initially in the US in the 1980s.

The purpose of timebanks is to provide a creative remedy to social symptoms of modernity - isolation and alienation. Unhappy about the perceived paternalising attitude in public services and the disregard of the skills of "ordinary people", timebanking activists aim to institutionalise an empowering do-it-yourself approach. One of the cultural root causes behind modern alienation appears to be the hegemonic conception of economic activity, which is based on the atomistic market subject, along with the dissociation of economic relations (producer/recipient, producer/product, etc.). Timebanks, in contrast, emphasise the idea of coproduction, referring both to the importance of the conduct of the "recipient" of the service in determining the nature of the service (Boyle \& Harris, 2009; Parks et al., 1981) and to the role of social interaction more generally.

The system emphasises the equal value of everyone's time, with the implication that the capitalist market assesses value incorrectly (by creating arbitrary distinctions between valuable and non-valuable skills). The objective is to "recognise people as assets" (Boyle, Slay \& Stephens, 2010) in contrast to treating them as expenses. The purpose is not only to make use of idle skills but also to "rebuild the social fabric" (Boyle \& Bird 2014, p. 17). Timebanks are 
typically community based: while there are hardly any limits to who can join a timebank, the members tend to be local people.

In addition to making use of valuable and idle skills, thus creating new activity, timebanks also insist on an idea of value, which recognises existing but undervalued activity. Recognising this undervalued activity means making the "core economy" visible. This concept refers to daily work in and around the household and the community and the role of such work as an essential part of the economy, rather than a set of fringe activities or non-productive activities (Cahn, 2009; Coote, 2010; Goodwin et al., 2003; Stephens, Ryan-Collins \& Boyle, 2008). To use timebanking pioneer Edgar Cahn's metaphor, the core economy can be seen as the "operating system" of the more visible capitalist economy: one tends to ignore its importance until it is in disrepair (Cahn, 2004, p. 53-55). Yet crucially, timebanks do not see themselves as being confined to the realm of the core economy but rather seeing its proper recognition as one of their functions.

While timebanking is based on a clearly articulated philosophy, this philosophy allows variation on the level of membership and organisation. First, a single timebank can have thousands of members or as little as below a hundred. Also, membership can be either general or "targeted". The latter means that members are sought specifically from a given target group. For instance, a timebank can have the purpose of integrating immigrants or people with given health issues to the community. Second, timebanks' mode of organisation varies. Some timebanks have salaried co-ordinators (or "brokers"), while others are member operated and compensate all work for the timebank with "time currency" only. Further, some timebanks are standalone timebanks, while others are embedded in NGOs (Collom, Lasker \& Kyriacou, 2012).

\section{Timebanks in the UK and Finland}

In the UK, timebanks have existed since 1998 (Timebanking UK, 2017), and, indeed, the UK is given status as the place of origin of timebanking in Europe. The UK timebanks have developed into something of an institutionalised form of alternative economy. Timebanking UK lists currently over 300 timebanks of different sizes and orientations (Timebanking UK, 2017). Almost all of them rely on salaried brokers; this is partly due to the preference for a more conventional model of organisation and partly to the level of digital literacy. Complete selforganisation requires a completely digital system for skills/needs announcements, which not everyone is necessarily able to use, leading to 
"platform exclusion", particularly amongst the target groups of timebanks with a social-policy orientation.

In Finland, timebanking began in 2009, although somewhat similar systems have existed for a long time. STAP (Stadin Aikapankki, the Helsinki timebank) was founded in 2009 (Stadin Aikapankki, 2017). Currently, about 20 timebanks are listed countrywide (Suomen Aikapankit, 2017), but, practically speaking, a large number of them are inactive, meaning that timebanking is geographically concentrated in the capital. STAP is large and fully member operated. ${ }^{1}$ While it generally is a standalone timebank with no target group, one major NGO project, targeting people with mental/physical health issues, has used the timebank's platform.

In the absence of a salaried broker, the timebank noticeboard is fully digital. While the level of internet access in Finland is generally high, the digitalised system of organisation might nevertheless create an implicit selective pattern in membership. Indeed, members are socio-economically predominantly middle class, although this conceals variation. Ideologically, Finnish timebanks tend to emphasise a transformative, or political, approach and strictly member-run organisational preferences, while the UK timebanks see their function more in terms of social intervention.

\section{The Social Space and Upscaling}

All community economies need social space for functioning. Social space refers here to two separate, but connected issues.

The first is what is termed ontological space. Ontology can be defined as the study of what fundamentally exists and what wants to exist in the social world (Lawson, 2015). Social ontology is, then, the analysis of categories that organise the social world, assumptions regarding the dynamics of these categories and the emergence of new categories (Lawson, 2015, p. 21-22). An underlying idea is that the existence of given social entities depends on social institutions (Searle, 1995).

Second is the operating space amidst governance. Systems of governance organise human activity by creating norms, laws, incentives and political goals, eventually aiming at the diffusion of the logics and priorities of governance into

\footnotetext{
1 As an exception, one project with salaried personnel and external funding used the STAP accounting system. It was conducted 2013-16 (Aika Parantaa, 2017).
} 
social life at large. Any emerging organisation will have to negotiate its position in relation to the system of governance - in other words, what kinds of adaptation pressures it faces when being pushed to a given category and governed under it.

To give an example, a "market" only exists after it is constructed in social practices that institutionalise its logic (Callon \& Muniesa, 2005). Inevitably embedded in social relations, the key question related to the existence of "the market" is, then, whether it is recognised as an ontological entity. Once recognised as such, the market comes to be seen as a natural system of valuation. It also becomes governed with specific terms. Similarly, the question regarding the prospects of timebanking is what the prospects of establishing a distinct social sphere of valuation and governance ("community", "commons") are. If timebanks are seen as operating within such a distinct category, a specific approach is required; if not, they become easily interpreted and thus also governed in terms of pre-existing and dominant categories. Indeed, reference to social ontology is vital in explaining government responses to timebanks.

The ideology of timebanking insists that timebanks function in a sphere distinct from the hegemonic government/market dichotomy: commons, self-organised institutions, and "the community" (Seyfang \& Smith, 2002). Further, its very logic of functioning transcends key dichotomous categories of modern society and modern imagination. The most important dichotomous categorisation is public sphere/market sphere. The category of community also transcends the dichotomies of home/market and private/public. Further, timebanking transcends the boundaries between commercial and voluntary, money and social activism and, in many cases, also professional assistance/helping out as a peer.

The following question, in terms of both ontology and politics, is, then, what the conditions or prospects of the recognition of a distinct social or ontological space are, not being reduced to existing categories such as public service provision, volunteerism or commercial transactions. The issue needs to be analysed both in terms of government and market responses and in terms of reactions from timebank organisers to these responses. As timebanks cannot occupy a contained or isolated social space, they inevitably engage in implicit or explicit negotiations with these other spheres of organising. This negotiation is intensified by the attempts of timebanks to scale up further (Boyle, Coote, Sherwood \& Slay, 2010).

Scaling up in community economies means that locally originated systems are institutionalised and diffused through knowledge aggregation (Geels \& Raven, 
2006, p. 378). Yet, scaling up (Utting, 2015), or "diffusion" (Seyfang \& Longhurst, 2016), has various meanings. First, it can mean that a practice spreads geographically - in this case, more communities with timebanks. Second, it can mean that practices are embedded in new kinds of institutions. For example, new NGOs can discover timebanking as a method. Third, it can mean substitution: some services previously exchanged only through the capitalist market are offered in timebanks, thus shifting timebanks towards small-scale entrepreneurship. Fourth, it can mean growth of the volume of exchanges or members within an individual timebank or timebanking generally. While "diffusion success is dependent on a number of factors and ... is beyond the control of any given actor (or set of actors) to simply ensure that these elements are aligned" (Seyfang \& Longhurst, 2016, p. 20), all these forms of scaling up (diffusion) potentially imply different strategies and attract different responses from governments.

The question of social space typically becomes acute when a system of an alternative economy no longer needs to be "shielded" (Raven, 2012, p. 126) or contained in "protective spaces" (Smith \& Raven, 2012) but rather embedded and diffused in wider society. Yet, existing literature on these alternative economic systems, or "niches", appears to see the conditions of upscaling to exist almost exclusively in the context of a disruption of the existing system of governance. For instance, Gill Seyfang and Neel Longhurst write in their study on the diffusion of economic alternatives: "landscape pressures and regime 'crises' can be a necessary precursor for niche innovations to gain influence" (2016, p. 3).

While indeed true, this notion hardly contributes to understanding the prospects of institutionalising and upscaling timebanks in contexts with no acute regime crisis in sight. The regime in countries where timebanks have gained influence is quite stable, in whatever sense one wants to understand "regime": the government (with an interest in taxation, workforce control, upholding market institutions and market discipline, social-policy interventions, social coherence and crime prevention), or the prevailing capitalist economic system (interested in commodification and upholding the market discipline in valuation). The analysis of external pressures to timebanks in terms of maintaining, defending and negotiating their social space has to be carried out in contexts without major disruptions. 


\section{Data, Method and Epistemology}

The research data is comprised of interviews, observations and background materials. In Finland, long-term observation and resulting field notes (Kawulich, 2005) form the core of the data, while in the UK, the main data collection method was interviewing. Therefore, the UK data is more exploratory, yet more systematic.

Observations in Helsinki span a long period of time and include several sources of information (Strauss \& Juliet 1994). Indeed long-term observation over several years with a varying level of intensity was a practical possibility in Finland because of the author's residence. This observation took place in timebank member meetings and seminars on timebanking, including dialogue with politicians and government officials, etc. There was also regular contact with key timebank activists, who formed a loose group of 4-10 persons. Timebank organisation and challenges with authorities were regularly discussed with this group. The field notes resulting from this observation are based on a wide range of sources, as is typical to observation: informal interviews, lectures, seminars, expert group meetings, newspaper articles, internet mailing lists and so forth (Ralph, Birks \& Chapman, 2014).

In the UK, 10 brokers and/or active members from six timebanks in southeast London area were interviewed, along with a Timebanking UK staff member and local council employees in southeast London. These timebanks, as is typical in the UK, were small timebanks with salaried brokers. In terms of organisation and membership selection, the sample included both standalone and embedded, and both targeted and non-targeted timebanks. The format of the interviews was unstructured. The method of interviewing extended to the realm of "creative interviewing", understanding the interview as a "contextually bound and mutually created story" (Holstein \& Gubrium, 1995). Thus the interviews were also about sharing thoughts (Douglas, 1985), committing intentionally the "capital offense of interviewing" (Fontana \& Prokos, 2007, p. 40): answering questions from interviewees and allowing the interviews to have a dialogical format. This was done for purposes of ensuring the relevance of data, as the respondents were also asked to reflect on the particularities of their situation, which required comparisons with timebanking in Finland in the context of this research.

Despite the absence of fixed questions, a set of key themes was discussed with each interviewee. In the interviews with the timebank brokers/members, questions focused on: a) practical organisation of the timebank, b) trust-building amongst members (existing and potential), c) possibilities and limits of scaling 
up the activities and d) future challenges. The interview with the Timebanking UK staff member covered future plans and prospects of timebanking generally, as well as general political issues of concern to timebanks in the UK. Interviews with local council employees focused on how they see timebanks in relation to the council's policy objectives.

Other material includes, first, member surveys. During the interviews (2016), the author was provided the member survey of a well-established and large southeast London timebank. In addition, the author carried out a STAP member survey in 2014, which still has relevance. Further, a large number of other material was used: ministry and council position papers on timebanking, info leaflets and other similar material produced by individual timebanks, material produced by Timebanking UK and case studies available on the web pages of Timebanking UK and Timebanking USA (e.g. Boyle \& Bird, 2014; DBIS, 2015; DWP, 2015; Forest Time Bank, 2010; Simon, 2010; Timebanking UK, 2017). The variety of types of material draws from an attempt to maximise relevant information by allowing several data collection methods. The interviews and observations served as primary data sources and were complemented by member surveys and documents.

The applied methodology stresses a non-positivist approach: the social world needs to be analysed not only in the sense of "what happens" but also in the sense of how individuals make sense of it (Miller \& Glassner, 2011). This is important because of the performativity in social sciences: if the timebanks are to establish their social space, this requires establishing this space also within the realm of language in order to make it "real" in social ontology. In this sense, "interpretation" can precede "event", making them less separate also on the level of data collection.

In the data analysis, interview data and observation notes were transcribed, followed by a thematic categorisation (on thematic analysis, e.g. Guest, MacQueen \& Namey, 2012). The data was then organised following the ontological categories and entities with which timebanks negotiate their social space.

The resulting analysis is presented in the following chapters. The presentation is in the form of description of analysis results, presented as processed information rather than, for example, lengthy interview quotes. As the study is exploratory in nature, the narrative is not organised strictly as a balanced comparison; rather, each subchapter highlights the key points in both casestudy countries in light of the research question. 


\section{Government Responses: Market and Labour}

I will next analyse government responses to timebanking. By "government", I refer to any branch of government or administration that pays attention to timebanks. While governments do respond to timebanking, there is no little need for high-level politicians or most departments in the administration to do this.

In Finland, the major issue timebanking has faced is tax liability. Finnish tax officials announced, some years after the launch of the STAP, that services exchanged through timebanks should be reported to the tax authority in their euro value, as the timebank generates economic benefits to its members (Joutsenvirta, 2016). The existence of an accounting system was interpreted by the tax officials as an indication that timebanks resemble market exchange. Timebank activists have constantly (and with little success) attempted to challenge this interpretation. "Compensated labour" seems to be taken by the tax office as a non-negotiable category and is seen as challenging the very institutional basis of the welfare state. The position of the tax office thus creates a permanent obstacle to upscaling timebank activities in terms of substituting market activity as, in order to comply with the interpretation on tax liability, timebanks should see to it that all professional activities are excluded.

The self-perception of the system of government in the country displays adherence to the welfare-state tradition. This tradition is based on a combination of high commodification within the market sphere and high decommodification within the sphere of social services, to use Gösta Esping-Andersen's terms (1990). As an implication, the taxation system penetrates the economy efficiently in order to cater for the generous public and decommodified sphere. Practices resembling the market in any way are therefore easily interpreted by government officials as liable to taxation.

In the UK, in contrast, taxation appears to have been no serious concern to timebanks at any point. Yet the control of unemployed persons has been pushed quite far, and timebanks have faced pressure from job centres. Job centres expect the unemployed to be full-time active job seekers, and they initially expressed suspicion of job seekers' activities within timebanks. Timebanking UK has managed to negotiate timebanking as an activity legitimately counting towards the required job-seeking time. Although pushed by Timebanking UK itself, this approach leads to a new form of control of the unemployed, as job seekers need to produce their timebank transcripts in job centres. Today, many job centres actively direct unemployed people to local timebanks; some are even introducing their own timebanks to keep job seekers occupied. 
The Department of Work and Pensions (DWP) stated that "claimants involved in 'timebanking', or 'time-exchange schemes', are regarded as making a positive contribution to the community and are encouraged to do so ... However, claimants must still meet the other conditions of entitlement ... Any participation in timebanking must be declared immediately to DWP" (2015). Jobcentre work coaches are instructed to "check that the requirements of the opportunity will not prevent a job-seeker from meeting key labour market conditionality requirements" (DBIS, 2015, p. 15).

Yet the position taken by the DWP does not and cannot completely do away with tensions related to the potential conflict between timebanks and the labour market. As market discipline requires non-interference in market competition, activities within timebanks are always potentially illegitimate from this perspective - in economics parlance, they might be seen to "create market disturbances". For instance, an unemployed professional painter might use his/her skills to paint a house and earn time credits on the way, but there will most likely also be other painters searching for work, who will be unhappy about the unemployed painter "selling below market prices".

Thus the recognition of the positive contribution of timebanking also masks a tension: the job centres are interested in both limiting the professional-type activity of the unemployed (to avoid market disturbance) and in encouraging professional activity (to uphold the employability of the unemployed). In a rhetorical attempt to overcome the tension, the Department of Business, Innovation and Skills says that job-centre staff can direct job seekers to timebanks "as a way to build up their experience" (italics added), thereby using the currently dominant labour policy discourse, which focuses on employability rather than employment directly. (On employability, see Mitchell \& Muysken, 2008, chapter 5.)

\section{Governing the Volunteer Sector}

In addition to subjecting timebanks to governance via economic categories (income, labour), timebanks can be governed by the government by pushing them into the "volunteer sector" category. This categorisation then pushes timebanks into another category of dominant social ontology. The volunteer sector should be seen as a governed domain: it does not mean only legitimate social space for spontaneous civic activity. The sector is governed through the means of planning, monitoring, target-setting, financial incentives and attempts to align the sector with government policies. This is particularly visible in the UK Big Society model. As community-level activity is not necessarily in line with 
political objectives, Big Society governance involves attempts to align community activity to contribute towards government policy goals (Alcock, 2010).

The government's relationship with the volunteer sector is not confined to its promotion. The government also actively shapes the sector by means of channelling financial assistance to volunteer organisations and by implementing specific volunteering strategies. There are explicit schemes to encourage and even commodify volunteering. Yet volunteering is also seen as a tool to withdraw from funding public services. Sometimes the co-existence of austerity and volunteerism is expressed as an explicit model, while on other occasions volunteerism is rather seen as a survival strategy for public services. In the words of an interviewed local council employee: "Austerity is not going away. We have to find ways to live with it. If it requires establishing a 'friends of the local library volunteer society' to avoid closing down the local library; I think we should do that". Volunteering strategies very explicitly place timebanks within this governable category.

Interestingly, the UK government's strategy to encourage and govern volunteerism gives rise to initiatives that both compete with timebanks and repackage their ideology in a more market-friendly language and form. For instance, a project called "Spice" (Spice, 2017) aims at generating volunteerism by creating incentives. This is done by giving vouchers to volunteers in accordance with "hours" earned in volunteering. The vouchers can be used to get reduced prices from local services, or, for example, free entry to museums. Spice uses the time currency and co-production language of timebanks, but its idea is more in line with the government's ambitions.

In Finland, similar attempts to categorise timebanks within the volunteer sector have not been seen, as the government interpretation of timebanking has been based on an economic vocabulary, emphasised by the preferred non-formal mode of organisation of timebanks, making it considerably more difficult for the authorities to govern the activities as volunteerism.

\section{Pressures from Commercial Agents}

Pressures on timebanks do not derive only from the government. Timebanks also sometimes have to consider whether they enter into relations with commercial agents. For instance, despite their community-building ideology, timebank organisers do not necessarily find it easy to assure people they should let strangers with no professional status into their homes. This has led to a 
general tendency to restrict the scope of offered services ${ }^{2}$, as well as a reliance on a private insurance scheme. Timebanking UK points out that the first claim on its collective insurance scheme is still to be made, yet argues that the very existence of the scheme is significant in convincing people that timebanking activities are safe (2017).

Interestingly, the insurance company initially displayed a lack of understanding regarding timebanks, clearly overpricing the scheme. While the terms of the scheme were eventually renegotiated, the decision to buy private insurance opens a new arena of negotiation, in which timebanks have to defend their logic of operation against the logic of a capitalist market agent. Insurance also defines some exchanges as out-of-bounds, including professional construction, electricity, etc., thus being in conflict with the timebank philosophy of making use of all idle and useful skills (Cahn, 2004). Timebanks ultimately have had to accept the limitations defined in the insurance terms.

The felt need to rely on insurance highlights the importance of "social goods", the most noteworthy of which is a high level of trust within the society. The welfare-state tradition appears to be better in the provision of such goods; in contrast with reliance on commercial insurance in UK timebanks, Finnish timebanks have not felt a need for such external assurance but have relied on their internal ethical codes and conflict-resolving procedures. Mutual trust amongst members is not only an outcome of suitable procedures within the timebank but the general societal atmosphere (equality, institutional quality) is also a significant contributing factor, as joining timebank activity means engaging in personal interaction with strangers. This general atmosphere, while being a major enabling/disabling factor, is extremely hard to change by the timebank activists themselves.

Interestingly, the Finnish tax authority and the UK insurance company push quite similar limitations on professional activity in timebanks. While the former draws justification from reference to economic benefit and the latter from risk

2 One UK timebank broker said in the interview: "I will do anything but childcare. Childcare is a can of worms." Another listed out-of-bounds issues to be "electricity, plumbing, gas, construction, handling money, pets, high places... We have to think in terms of what could happen." These limitations are interesting as in the Finnish context, many of these services, especially childcare and pet minding, are amongst the most used. 
assessments, both create a pressure to contain timebanking activities to routine help around the house and other non-professional activities.

\section{Timebank Responses}

As timebanks always operate in the context of society with existing governance procedures, functioning, in general, and scaling up, in particular, force timebanks to make difficult choices regarding the terms of integration with existing orders of valuation, justification and governance. In the UK, timebanks have made an explicit and conscious effort to "sell" the timebanking concept to potential funders, as the salaried broker model of organisation creates a constant need for funding. This funding is typically sought from funds available to the volunteer sector.

The felt need to convince funders has two kinds of consequences: first, not all timebanks focus on community building in the general sense but rather on given target groups. The target-group approach was seen by the interviewees either as a genuine reflection of the identity of UK timebanks or as the reality they have to live with, in other words, an unavoidable fundraising issue. When approaching potential funders, timebanks tend to present their work in terms of documentable social benefits. While timebanks are not social-policy instruments as such, the concept is easier to sell if portrayed as a creative remedy to some identified social ill. As timebanks are presented as amongst social interventions (and thus also competing for funding with other social-policy approaches), they also enter into comparisons with these "competitors".

Second, timebanks tend to seek methods of justification, which effectively enable scaling up in the short term but might be an obstacle for pushing a transformative idea of value. Several UK timebank brokers refer to the need to document the impacts of timebanking, especially showing that there are measurable outcomes on certain target groups. This clearly deviates from more ideological (and ambiguous) goals such as community building, creating an alternative conception of value, etc. Interestingly, while several Finnish timebank activists oppose the idea of reducing the value of timebanking to quantifiable figures, some of them, nevertheless, have referred to such tools as ultimate methods of justification when confronted by the tax authority.

The most often-used impact assessment tool is the Social Return on Investment (SROI) methodology (Social Value UK, 2017). It is mostly used to convince authorities that well-being generated by timebanking leads to diminished expenses in social services and health services. On the other hand, SROI is sometimes promoted as formalising an alternative conception of value ("social 
value"). Therefore, somewhat paradoxically, the methodology implies that value created in timebanking is both commensurable with other social interventions (as the returns on the social investment can be quantified) and incommensurable with capitalist value (as it entails a unique conception of value). It is indeed debatable whether SROI is indeed a strategic tool for defending the timebanks' conception of value or a shift towards a capitalist conception of value.

Some timebanks in the UK have quite deliberately chosen the strategy of cooptation in the face of pressures from the government. For example, given their criticism of the market logic of valuation, one would assume that this also extends to criticising the control of the workforce in job centres. Yet timebanks have not protested the approach chosen by job centres (which embrace timebanking but insist on conditionalities and reporting) but rather have seen it as a recognition of the social value of timebanking. As one timebank explains to potential unemployed members in an info sheet: "Jobcentre Plus may ask for information about what exchanges you have undertaken. Don't worry. Every month, we give you a statement of your exchanges that you can show them" (Forest Time Bank, 2010).

Another form of co-optation relates to accepting the government perception of timebanks as spaces for gaining and building experience that can then be utilised within the "economy proper". Timebank ideology does not accept making such sharp divisions between market and non-market as the market is seen as a misguided mechanism for determining the value and need for a given skill. Advocacy for timebanking promotes exactly the value of operating outside the category of salaried labour: "Any official objective of full employment - one that regarded paid employment as the only acceptable status for healthy adults of working age - undermines local efforts" (Boyle, Clark \& Burns, 2006, p. x-xi). The quoted statement is not in opposition to building experience, yet it emphasises valuing skills as such, rather than as means to achieve "real" employment in the future, as the concept "experience" indicates.

In Finland, timebanking involves more sense of activism. The need to challenge "conventional money" tends to be emphasised (CES, 2017a, 2017b). This is ideologically close to the "positive money" movement and other calls for radical monetary reform (Lietaer, 2001; Lietaer \& Belgin, 2011). Yet, relying on input from activists can lead to challenges with institutional continuity. Also, the taxation issue remains paralysing. Before the intervention by the tax authority, the volume of exchanges was more than double the present level. Currently, timebanks can try to live with the status quo and operate despite the tax office 
ruling, as long as the tax office does not actively enforce taxation on timebanking by, for example, demanding lists of transactions. However, their suspicious legal status deters potential timebank members and thereby suppresses growth. Several NGOs in Finland have expressed their interest in using the timebanking platform to recognise the input of their volunteers or to create embedded timebanks, but are concerned about the perception of timebanks as bordering on illegal.

Not many Finnish timebanking activists appear to see the Big Society model as an ideal, despite its explicit recognition of timebanking. Rather, the importance of the production of social goods is often emphasised. This is in line with the "partner state" approach in commons theory (Bauwens, 2012; Bauwens \& Kostakis, 2014). One proposal in this spirit is to implement taxation but on timebanks' terms. STAP already collects a "time tax", a small levy in time currency subtracted from each transaction. This levy is used to compensate activists for necessary operations within the timebank (maintenance of software, member register, etc.). Thus the time tax can be seen as a time-based funding for infrastructure maintenance in a self-governed system (Eskelinen, Kovanen \& van der Wekken, 2017). This model has been suggested as a possible basis for solving the taxation issue: for instance, a municipality could theoretically open a timebank account and receive similar levies in time currency. This would imply recognising the conception of value in timebanking, rather than solving the taxation issue by enforcing the capitalist conception of value.

\section{Discussion and Conclusions}

The analysis above shows that the ontological space available for timebanks is often limited. When aiming to scale up, timebanks often encounter pressures to compromise by assuming the narrative of some existing category. Advocacy for timebanks also often relies on existing categories instead of insisting on the recognition of the logic and values of the commons (which would imply transcending the state/market dichotomy, as well as emphasising community and social interaction as bases of value). For instance, politicians sympathetic to timebanking in Finland are considerably more prepared to demand freedom from tax liability (assigning timebanks to a volunteering category) than to support the time-tax model (which implies transcending existing categories).

While, technically, timebanks are based on a uniform ideology worldwide, the strategic choices and dilemmas they face, and thereby also their operational choices, are shaped by local systems of governance and informal social institutions, rather than merely organisers' autonomous preferences. The local 
political context is reflected even in perceptions of typical activities within a timebank. When asked to provide an example of a typical exchange, timebank brokers in the UK refer almost invariably to gardening, while in Finland, the typical exchange would be childcare (which would be seen as a safety/insurance issue in the UK). The chosen approach to these choices and dilemmas is also likely to shape the future forms of timebanking as timebanks are markedly open processes rather than fixed institutions.

In Finland, the high commodification/high decommodification welfare-state tradition of governance has been quick to see anything resembling "economic" as subject to taxation. Indeed, the government has insisted that timebanks produce economic benefits for their members. On the other hand, the welfare state can also be enabling, especially by fostering a general atmosphere of mutual trust (Larsen, 2007; Rothstein, 2001). In the UK, in sharp contrast to Finland, timebanks are actively endorsed by government bodies, in line with the Big Society ideology. Yet this does not mean that timebanks do not face external pressures. These pressures come from both the government and the market and relate to labour-market conditionalities and insurance. Further, within the Big Society framework, while the search for social space has not been a struggle for the recognition of timebanking as such, there have been challenges related to self-organisation amidst government attempts to govern the volunteer sector, insisting that timebanks fall within this category.

Also, the prospects of scaling up are different. On the basis of the typology presented in this article, it seems that the UK timebanks have expanded very successfully geographically, as well as in terms of being embedded in new institutions. Timebanking in Finland is geographically concentrated and suffers from the status of being perceived as bordering on illegal. Generally, the taxation issue creates obstacles for scaling up in the sense of including new kinds of activities and attracting NGOs to create embedded timebanks. Yet, seeking a positive response from the government is no real solution as this involves pressures to accommodate timebanking within categories preferred by the government, as seen in the case of the UK.

The social space of alternative economies is still in the making. It is easy to see timebanks as a method for encouraging small-scale community-based activity (helping neighbours, exchanging services, volunteering for the community, etc.), but seeing this as the exclusive rationale of timebanking fails to recognise its full essence. Similarly, interpreting timebanks in terms of economic exchange (as the Finnish tax office does) can be tempting but also misses significant 
aspects. A more credible approach would place civic activism as its starting point: timebanks are precisely about transcending categories.

The relationship of alternative economies (as transcending categories) with different forms of government calls for research in the future. This further research could take three possible directions to complement the exploratory research presented in this article: first, the ontological space available for timebanks could be compared with other alternative economies; second, research could be carried out with settings allowing proper country comparisons; third, further research could go into more detail regarding the relationship between ontology and organisation. While this article has presented starting points for studying alternative economies from the point of view of social space and social ontology, there is considerable room for further research.

\section{References}

Aika Parantaa. (2017). Tovituki Tunnetuksi Hanke. Retrieved from http://www.aikaparantaa.net/tovituki-tunnetuksi-hanke.html

Alcock, P. (2010). Building the big society: A new policy environment for the third sector in England. Voluntary Sector Review, 1(3), 379-389. https://doi.org/10.1332/204080510X538365

Bauwens, M. (2012). Blueprint for P2P society: The partner state \& ethical economy. Shareable.net. April 7, 2012. Retrieved from http://www.shareable.net/blog/blueprint-for-p2p-society-the-partner-stateethical-economy

Bauwens, M., \& Kostakis, V. (2014). Network Society and Future Scenarios for a Collaborative economy. Basingstoke: Palgrave MacMillan.

Benkler, Y. (2006). The Wealth of Networks: How Social Production Transforms Markets and Freedom. New Haven, Connecticut: Yale University Press.

Botsman, R., \& Rogers, R. (2011). What's Mine Is Yours: How Collaborative Consumption Is Changing the Way We Live. London: Collins.

Bollier, D., \& Helfrich, S. (Eds.). (2012). Wealth of the Commons. A World Beyond Market and State. Amherst, Mass.: Levellers Press.

Boyle, D., Clark, S., \& Burns, S. (2006). Hidden Work: Co-production by People outside Paid Employment. York, UK: Joseph Rowntree Foundation.

Boyle, D., \& Bird, S. (2014). Give and Take. How Timebanking is Transforming healthcare. Stroud: Timebanking UK.

Boyle, D., \& Harris, M. (2009). The Challenge of Co-production. London: NESTA / New Economics Foundation.

Boyle, D., Slay, J., \& Stephens, L. (2010). Public Services Inside Out. Putting coProduction into Practice. London: NESTA / New Economics Foundation.

Boyle, D., Coote, A., Sherwood, C., \& Slay, J. (2010). Right Here, Right Now. Getting Co-production into the Mainstream. London: NESTA / New Economics Foundation. 
Cahn, E. (2004). No More Throwaway People: The Coproduction Imperative. Washington, DC: Essential Books.

Cahn, E. (2009). It's the Core Economy Stupid: An Open Letter to the Non-Profit Community. Retrieved from http://trustcurrency.blogspot.fi/2009/12/its-coreeconomy-stupid-open-letter-to.html

CES [Community Exchange System]. (2017a). Why We Need a New Exchange System Retrieved from https://www.community-exchange.org/home/how-it-works/whywe-need-a-new-money/

CES [Community Exchange System]. (2017b). The Problems with Conventional Money. Retrieved from https://www.community-exchange.org/home/qanda/theproblems-with-conventional-money/

Callon, M., \& Muniesa, F. (2005). Peripheral vision: Economic markets as calculative Collective devices. Organization Studies, 26(8), 1229-50. https://doi.org/10.1177/0170840605056393

Collom, E., Lasker, J., \& Kyriacou, C. (2012). Equal Time, Equal Value. Farnham: Ashgate.

Coote, A. (2010). The Great Transition: Social Justice and the Core Economy. London: New Economics Foundation.

Coote, A. (2011). Big society and the new austerity. In M. Stott (Ed.), The Big Society challenge (pp. 82-94). Cardiff: Keystone Development Trust.

DBIS [Department for Business, Innovation and Skills]. (2015). Independent Review of the Sharing Economy: Government Response. Retrieved from https://www.gov.uk/government/uploads/system/uploads/attachment_data/file/4 14111/bis-15-172-government-response-to-the-independent-review-of-thesharing-economy.pdf

Douglas, J. (1985). Creative Interviewing. London: Sage.

DWP [Department of Work and Pensions] (2015). Department of Work and Pensions Statement on Timebanking. Retrieved from http://www.timebanking.org/wordpress/wp-content/uploads/2015/12/DWPStatement-Flyer.pdf

Eskelinen, T., Kovanen, S., \& van der Wekken, R. (2017). Self-organisation in solidarity economies. The Finnish Journal of Urban Studies, 55(3), 76-80.

Esping-Andersen, G. (1990). Three Worlds of Welfare Capitalism. Princeton, NJ: Princeton University Press.

Fontana, A., \& Prokos, A. (2007). The Interview. From Formal to Postmodern. Walnut Creek, CA: Left Coast Press.

Forest Time Bank (2010). Timebanking and Your Benefits. Retrieved from https://foresttimebank.files.wordpress.com/2010/09/benefits-and-volunteeringv5-0.pdf

Geels, F., \& Raven, R. (2006). Non-linearity and expectations in niche-development trajectories: Ups and downs in Dutch biogas development (1973-2003). Technological Analysis and Strategic Management, 18(3/4), 375-392. https://doi.org/10.1080/09537320600777143

Gibson-Graham, J.-K. (2008). Diverse economies: Performative practices for 'other worlds'. Progress in Human Geography, 32(5), 613-632 https://doi.org/10.1177/0309132508090821

Goodwin, N., Nelson, J., Ackerman, F., \& Weisskopf, T. (2003). Microeconomics in Context. New York: Houghton Mifflin. 
Guest, G., MacQueen, K., \& Namey, E. (2012). Applied Thematic Analysis. London: Sage. https://doi.org/10.4135/9781483384436

Healy, S. (2009). Alternative economies. In R. Kitchin \& N. Thrift (Eds.), International encyclopedia of human geography (pp. 338-344). Amsterdam: Elsevier. https://doi.org/10.1016/B978-008044910-4.00132-2

Holstein, J., \& Gubrium, J. (1995). The Active Interview. London: Sage. https://doi.org/10.1016/B978-008044910-4.00132-2

Joutsenvirta, M. (2016). A practice approach to the institutionalization of economic degrowth. Ecological Economics, 128, 23-32. https://doi.org/10.1016/j.ecolecon.2016.04.006

Kawulich, B. (2005). Participant observation as a data collection method. Forum: Qualitative Social Research, 6(2), art.43

Laamanen, M., \& den Hond, F. (2015). Prefigurative partial organization in local social movements: Examining decided and emergent order in a time bank. Proceedings from the 31st European Group for Organizational Studies Colloquium (EGOS).

Larsen, C. A. (2007). How welfare regimes generate and erode social capital. The impact of underclass phenomena. Comparative Politics, 40(1), 83-102. https://doi.org/10.5129/001041507X12911361134479

Lasker, J., \& Collom, E. (2011). Time banking and health: The role of a community currency organization in enhancing well-being. Health Promotion Practice, 12(1), 102-115. https://doi.org/10.1177/1524839909353022

Lawson, T. (2015). A conception of social ontology. In S. Pratten (Ed.), Social ontology and modern economics (pp. 19-52). Oxon: Routledge.

Lietaer, B. (2001). The Future of Money: Creating New Wealth, Work, and a Wiser World. London: Random House.

Lietaer, B., \& Belgin, S. (2011). New Money for a New World. Boulder, CO: Qiterra Press.

Miller, J., \& Glassner, B. (2011). The 'inside' and the 'outside': Finding realities in interviews. In D. Silverman (Ed.), Qualitative research (3rd ed., pp. 99-112). London: Sage.

Mitchell, W., \& Muysken, J. (2008). Full Employment Abandoned. Shifting Sands and Policy Failures. Cheltenham: Elgar. https://doi.org/10.4337/9781848441422

North, P. (2007). Money and Liberation: The Micropolitics of the Alternative Currency Movement. Minneapolis: University of Minnesota Press.

Ostrom, E. (2010). Beyond markets and states: Polycentric governance of complex economic systems. American Economic Review, 100(3), 641-72. https://doi.org/10.1257/aer.100.3.641

Ostrom, E. (1990). Governing the Commons: The Evolution of Institutions for Collective Action. Cambridge: Cambridge University Press. https://doi.org/10.1017/CBO9780511807763

Ozanne, L. (2010). Learning to exchange time. Benefits and obstacles to time banking. International Journal of Community Currency Research, 14, 1-16.

Parks, R., Baker, P., Kiser, L., Oakerson, R., Ostrom, E., Ostrom, V., \& Percy, S. (1981). Consumers as co-producers of public services. Some economic and institutional considerations. Policy Studies Journal, 9(7), 1001-1011. https://doi.org/10.1111/j.1541-0072.1981.tb01208.x 
Ralph, N., Birks, M., \& Chapman, Y. (2014). Contextual positioning: Using documents as extant data in grounded theory research. SAGE Open, 4(3), 1-7. https://doi.org/10.1177/2158244014552425

Raven, R. (2012). Analysing emerging sustainable energy niches in Europe: A strategic niche management perspective. In G. Verbong \& D. Loorbach (Eds.), Governing the energy transition: Reality, illusion or necessity? (pp. 125-151). Abingdon: Routledge.

Rothstein, B. (2001). Social capital in the social democratic welfare state. Politics and Society, 29(2), 207-241. https://doi.org/10.1177/0032329201029002003

Searle, J. (1995). The construction of Social Reality. New York: The Free Press.

Seyfang, G. (2003). Growing cohesive communities one favour at a time: Social exclusion, active citizenship and time banks. International Journal of Urban and Regional Research, 27(3), 699-706.

Seyfang, G. (2004). Time banks: Rewarding community self-help in the inner city? Community Development Journal, 39(1), 62-71. https://doi.org/10.1111/1468$\underline{2427.00475}$

Seyfang, G., \& Longhurst, N. (2016). What influences the diffusion of grassroots innovations for sustainability? Investigating community currency niches. Technology Analysis \& Strategic Management, 28(1), 1-23.

Seyfang, G., \& Smith, K. (2002). The Time of Our Lives: Using Time Banking for Neighbourhood Renewal and Community Capacity Building. London: New Economics Foundation.

Simon, M. (2010). Your Money or Your Life: Time for Both. Stroud: Timebanking UK.

Smith, A., \& Raven, R. (2012). What is protective space? Reconsidering niches in transitions to sustainability. Research Policy, 41(6), 1025-103. https://doi.org/10.1016/j.respol.2011.12.012

Smith, M. (2010). From big government to big society: Changing the state-society balance. Parliamentary Affairs, 63(4), 818-833. https://doi.org/10.1093/pa/gsq023

Social Value UK. (2017). Social Value UK. Retrieved from http://www.socialvalueuk.org/

Spice. (2017). Spice. Retrieved from http://www.justaddspice.org

Stadin Aikapankki. (2017). Miten Kaikki Alkoi? Retrieved from https://stadinaikapankki.wordpress.com/stadin-aikapankin-toiminnasta/stapperustustarina/

Stephens, L., Ryan-Collins, J., \& Boyle, D. (2008). Co-production: A Manifesto for Growing the Core Economy. London: New Economics Foundation.

Strauss, A., \& Corbin, J. (1994). Grounded theory methodology: An overview. In N. Denzin \& Y. Lincoln (Eds.) Sage handbook of qualitative research (pp. 273-284). London: Sage.

Suomen Aikapankit. (2017). Aikapankit Suomessa. Retrieved from http://www.aikapankit.fi/?page_id=13

Timebanking UK. (2017). What is Timebanking? Retrieved from http://www.timebanking.org/what-is-timebanking/

Utting, P. (2015). Introduction: The challenge of scaling up social and solidarity economy. In P. Utting (Ed.), Social and solidarity economy beyond the fringe (pp. 1-37). London: Zed Books. 